\title{
Specifics of proximal caries and their diagnostics in posterior teeth
}

\author{
Ilona Wojcik-Checinska ${ }^{1}$, Agnieszka Mojsym ${ }^{2}$, \\ AgnieszKa loj-Maczulska ${ }^{1}$, Renata Chalas ${ }^{1}$
}

\begin{abstract}
${ }^{1}$ Chair and Department of Conservative Dentistry and Endodontics, Medical University of Lublin, Poland
${ }^{2}$ Private Dental Practice in Lublin, Poland
\end{abstract}

\section{ARTICLE INFO \\ Received 15 April 2015 \\ Accepted 08 May 2015}

\section{Keywords:}

posterior teeth, approximal surfaces, caries, diagnostic methods.

\begin{abstract}
Proximal surfaces are the second in turn after the occlusal surfaces, as being the most exposed places to the carious process. The specificity of changes and location makes the diagnostic of approximal cavities difficult. The aim of the study was to collect information on possibilities of detection, monitoring and assessment of carious lesions located on proximal surfaces, starting from the early stage. On the base of current literature, chosen methods of diagnosis, from conventional, to advanced technologies were presented. Current literature also suggests that none of the diagnostic methods exclude the possibility of misdiagnosis of proximal caries. Therefore, during the diagnosing of doubtful cases, it is advisable to employ several methods of assessment, with simultaneous individual appraisal of caries risk factors, such as oral hygiene, frequency of eating sweets or the number of active caries foci.
\end{abstract}

Proximal surfaces, which are in a close or direct contact with the gum, are the second in turn (after the occlusal surfaces), of the most exposed places to the carious process. These surfaces are naturally protected from the influence of chewing forces, tongue movements and saliva flow, which contributes to the deposit of bacterial plaque and food debris in the spaces between adjacent teeth, and to the non-possibility of natural self-cleaning of these places. Changes in the structure of the surface by the loss of the enamel smoothness due to the development of caries, or restorations with overhanging (extending) edges, additionally, create conditions for the retention of plaque and reduce the possibility of its proper removal. As a result, there is an accumulation of plaque, and, subsequently, bacterial succession. The proximal surfaces in young people are completely filled with gingival papilla, and, thus, constitute less favorable living conditions for Streptococcus mutans. When the gum recedes in the direction of the root apex, on the exposed surfaces of the teeth, there is a greater exposure to bacterial colonization of Streptococcus mutans, which in turn stimulates their growth [15]. Isolation of bacterial species during the examination of proximal surface flora demonstrates that there are numerous streptococci and gram positive species

\footnotetext{
* Corresponding author

e-mail: renata.chalas@umlub.pl
}

of the genus Actinomyces spp. Moreover, when compared to the flora of cavities on the chewing surfaces, that found here are more strictly anaerobic species. The problem in studying the etiology of proximal caries comes down to the fact that it is difficult to identify the presence of early enamel lesions, and that while taking the swab, the samples are taken from the whole area between the teeth, not only from the demineralized surface, but also from the healthy enamel. In addition, the microflora can be very different in different places on the proximal surfaces, irrespective of the presence or absence of the cavity on the enamel surface. Therefore, the data concerning the relationship of specific species of bacteria with the development of caries on the proximal surfaces are not always clear [15].

Particularly exposed to the development of caries are the proximal surfaces of the posterior teeth. In the primary dentition, in regard to the first molars, these are mainly the distal contact surfaces, and, to a lesser extent, the mesial contact surfaces [2]. The presence of caries on the contact distal surface of the first deciduous molar is determined by the proximity of the second deciduous molar. In the case of the mesial contact surface, it should be noted that the first milk molar tooth and canine are positioned at a distance from each other, which undoubtedly facilitates self-cleaning and prevents the development of caries. In the second milk molar, besides the chewing surface, carious lesions are 
particularly common on the mesial contact surface, which is conditioned by its proximity with the first milk molar tooth. What is more, a severity of caries in the distal contact surface of milk molars is also observable. This is most likely related to the non-erupted yet first permanent molars. In the permanent dentition in children, the caries on the mesial contact surface of the first permanent molar is caused by the rather broad contact of this tooth with the distal surface of the second milk tooth, which hinders cleaning. Depositing of plaque in this area is favored by the frequent carious process of this primary tooth [27]. Therefore, difficulties and dilemmas in the diagnosis of caries initiating on proximal surfaces of posterior teeth are mainly due to the anatomical conditions, and the presence of an adjacent tooth further restricts the monitoring of these sites.

Precise diagnosis should, first of all, facilitate detecting, monitoring and evaluating the carious lesions at an early stage of the disease before it leads to irreversible tissue damage, so as to enable the dentist to take preventive and curative measures relevant to the stage of caries $[1,21]$. Selection of appropriate diagnostic tests for the detection of a specific disease is very important, and their task is to help bring about the correct diagnosis. The ideal diagnostic test has a high sensitivity (detects the existing disease) and high specificity (excludes a disease where it does not exist), it also must be reliable i.e. consistent with the results of a diagnostic reference test (i.e. the golden standard a test which offers the most reliable and accurate results). In addition, it should be repeatable (obtain the same results with the same investigator) and unambiguous (achieve the same results with different investigators), non-invasive for the patient, easy to use, helpful in making the diagnosis and cheap $[10,18]$. The reference point for the evaluation of new diagnostic methods is called "the golden standard". It is characterized - inter alia - by the reproducibility of the test. Besides this, it should take into account the anatomicpathological course of the disease and be independent of the diagnostic test evaluated. In the case of new diagnostic methods of caries, the most commonly used criterion - the point of reference - is the depth of the lesion as estimated by investigators basing their decision on histopathological, clinical or radiological tests $[8,28]$. Other applicable criteria include the progress of the lesion and the degree of bacterial infection [18].

Available and commonly used conventional methods of caries detection include visual assessment, probing and radiological examination. In the case of proximal caries, precise diagnosis appears to be of particular importance, because, as indicated by the results of research, these changes are asymptomatic, and in the vast majority of cases $(93.8 \%$ affected surfaces), patients do not report any symptoms [17]. The visual examination consists of the assessment of macroscopic changes: the change of color, translucency, smoothness and gloss, which occur in enamel and dentin with the progress of the disease. For such an examination, teeth should be cleaned and dried, while suitable lighting should be used. In the examination, magnification can also be useful. This can be achieved via loupe, intra-oral video camera, or the use of transillumination [5,17]. Proximal caries are detected by way of a clinical study (visual) and more often in an advanced stage affecting the dentin, and as the literature confirms, this method, however, is the least useful for early diagnosis, as it is limited to the enamel and to potentially reversible caries $[5,17,22]$.

Intra-oral video camera test results related to caries of occlusal surfaces of posterior teeth show low specificity for lesions located in the dentin, and, therefore, generate a large number of "false positives", which creates the risk of making unnecessary invasive treatment [5]. In her studies, MirskaMiętek obtained similar results with respect to lesions in the enamel on the proximal surfaces of posterior teeth [17]. The author explains away the result of her work by suggesting the possible remineralization of lesions that are in the form of a carious spot, and the development of a so-called tissue scar that is invisible on the radiograph, yet which is strongly marked in the high magnification of video camera [17]. The occurrence of these lesions in the enamel was also observed by Schmid et al. as early as in 1984, and deemed the 'fluoride syndrome'. By so doing, he explained the excessive mineralization of the enamel as something that comes about by contact with the more and more commonly used high concentrations of the fluoride used in the prevention of caries on the proximal surfaces [25]. Another method of visual assessment of the contact surfaces of the teeth is the tooth separation. According to Hintz et al., this method allows the detection of $50 \%$ more cavities, compared to the method routinely used in clinical examinations [9]. Herein, clinical evaluation of the carious lesions is based on a subjective interpretation of the dentist and his/her experience. The diagnostic efficacy of the method is characterized by a high specificity, but its sensitivity is low. It obliges the use of assistive diagnostic methods of caries, as based upon quantitative assessment.

Radiography is the most commonly used diagnostic method in the evaluation of proximal surfaces. It is also performed in asymptomatic patients, as part of a dental examination and a screening procedure [7]. In radiography, the loss of minerals in hard dental tissues in the course of caries is made evident. However, the degree of demineralization of tissue in order to be visible in a radiograph as a brighter surface (hence, indicating the presence of caries) as confirmed by various authors, must reach $5 \%-40 \%$ $[11,12,20]$. In radiographic imaging, the carious lesion on the proximal surface is recognized by its distinctive appearance. Depending on the degree of demineralization and the progress of the lesion, the change in the enamel is seen as a scratch or a vallecula/pit involving not more than half the thickness of the enamel cap (early caries). When the caries progresses, the brighter surface looks like a triangle or the letter "V", and exceeds half the thickness of the enamel. The advanced foci then occupy the entire thickness of the enamel and pass over the enamel - dentine edge, spreading out sideways [12]. It has been shown that the evaluation of the examination results of caries on the radiographs does not require a lot of experience - the degree of adequacy of the assessments made by the dentists with many years' experience and the students of the final year of dentistry was similar [16]. Difficulties in interpretation of radiographs are related to the presence of large fillings, big proximal surfaces and the overlapping of these surfaces when the 
teeth are tightly located. It is also related to the presence of a brighter surface being within the cervical area, or the presence of strongly mineralized sclerotic dentine, which in the radiograph, absorbs more radiation in relation to the primary dentin, and, therefore, the latter being confused with dental caries $[12,16]$.

In the diagnostic radiography of proximal caries, bitewing projections play a special role, as they allow for the evaluation of the mandibular and maxillary teeth on that side of the dental arch, from the distal surface of the canine, to the distal surface of the last molar. Taking two bitewing projections allows, therefore, for evaluating all of the posterior teeth, which significantly reduces patient radiation $[12,13]$. Bitewing radiography has also proven effective at detecting proximal caries. According to various authors, this method detects up to twice more cavities than a clinical examination alone $[8,16,17,22]$. Chłapowska and Żmijewska compared the detection of proximal caries by means of clinical examination and by transillumination and bitewing radiography in a group of 50 students. In their work, the highest percentage of carious lesions was recorded on the basis of the author's radiological examination $(27.1 \%)$, lower - with the help of transillumination $(21.6 \%)$ and clinical examination (17.0\%) [4]. Mirska-Miętek obtained similar results in a larger group of patients. Herein, the author assessed the prevalence of proximal caries at $98 \%$, and the technique of digital radiography in bitewing projection - as being the most effective method for the detection of early caries lesions in the enamel, allowing for detecting twice as many cavities than clinical examination, intra-oral video camera and transillumination. In contrast, the detection rate of advanced carious lesions in this work, with regard to all the evaluated methods, gave comparable results [17].

In order to minimize the radiation dose at a single exposure, digital radiography (RVG) is also applied [24]. Yet, many researchers and practitioners have critically evaluated its superiority over conventional radiographic images, especially for pediatric dentistry, in spite of its apparent advantages (among others, no need for film, ease of storage, image processing capabilities) [7]. In practice, however, the lower irradiation of the patient often turns out to be illusory, because the radiographic sensors are smaller than traditional film-based ones, and hence, this entails the need to perform multiple images in order to diagnose the whole dentition [17]. Hintze has also observed that the conventional bitewing projections were more effective at detecting caries at the proximal and chewing surfaces in children, over the bitewing digital images (that made by digital technology); the effectiveness being $25 \%$ and $19 \%$, respectively [7].

Wenzel and Fejerskov demonstrate that the detection accuracy of caries using radiovisography (RVG) is comparable to conventional radiography [29]. Based on current literature, it should be noted that the sensitivity of the RVG method in the evaluation of chewing and proximal surfaces does not exceed $50 \%$, while the specificity is at $90 \%[11,12,22]$. Taking into account the fact that in modern radioactivity protection, each dose of ionizing radiation is recognized to be potentially harmful, and the younger the body, the more harmful ionizing energy is, a dentist faces an important decision about the need and usefulness and the kind of radiographic image ordered [12,24]. Requesting of such an examination must always be preceded by the subjective and objective examination of the patient, the reading of the history of the disease and the consulting of previous radiological examinations [24]. This is supported by the studies of Haak et al. in detecting proximal caries, who showed that relying on the diagnosis of radiographs alone brings about $42-63 \%$ of the too early or unnecessarily undertaken surgical interventions [6].

Commonly used methods for proximal caries detection of posterior teeth, i.e. visual, visual-tactile, transillumination, radiography or magnification, are not fully satisfactory, although, reliable by modern standards. Thanks to the enormous progress in the field of advanced diagnostic methods, which now can discern the physical phenomena occurring in the tissues of any tooth affected by caries, modern dentistry has available devices that are able to detect the earliest signs of demineralization of enamel. To the profession, this offers a chance to stop the progression of changes and to avoid the need for corrective intervention. These include techniques utilizing the phenomenon of the absorption and scattering of light, conductivity and electrical resistance, reflections of sound waves and photoluminescence [11].

Following literature reports, however, there is no ideal tool which would determine the exact extent and the progression of changes $[1,21]$. One of the methods of diagnosing and monitoring carious lesions, and having high diagnostic accuracy, is the measuring of tissue fluorescence with a laser device - the DIAGNOdent Pen (KaVo, Germany) as adapted for diagnosing the proximal surfaces $[13,14]$. The operation of the device is based on a physical phenomenon in which the loss of minerals in the hard tissues of the tooth brought about by the carious process, changes their fluorescence - this being activated when exposed to laser light. Within the tooth hard tissue as changed by the presence of caries, the light absorption phenomenon occurs in proportion to the degree of demineralization. Herein, demineralized hard tissue of the tooth responds with a greater fluorescence (in the range $680 \mathrm{~nm}$ ) than does healthy tissue. The DIAGNOdent Pen is equipped with a sapphire probe to test the proximal surfaces, which deflects the laser beam by $100^{\circ}$, allowing an examining of the entire proximal surface of the tooth. What is more, the color code on the probe indicates the direction of incidence of the beam at the time of the examination. In contrast to the traditional methods, diagnostics with DIAGNOdent Pen may be helpful in assessing whether a carious lesion is reversible or not, and it can, hence, allow a determination of the extent of preventive or therapeutic procedures. The boundary between preventive treatments and therapy is the value of 30 as obtained on the device display. However, this value is questioned by some authors as being too high, because the carious process may affect dentin already at an indication of DIAGNOdent $18-21$ [14]. Of note, the use of this laser allows for the detection of changes in the enamel surface regardless of the experience of the physician. Moreover, it helps to assess the marginal integrity of fillings and difficult-to-reach places, yet it does not allow for the detection of secondary caries under the fillings $[11,13]$. 
The laser system under consideration facilitates retrieving/reproducing the results and their repetition. This option can be used in long-term observations of regression, progression of caries on proximal tooth surfaces $[3,14,30]$. According to Lussi, the DIAGNOdent Pen fully fulfills its role as an additional tool in the diagnosis of initial proximal carious lesions and is more sensitive than the digital bitewing imaging [14]. Yet, according to others, it is an unsatisfactory apparatus. This may result from the fact that the reliability of DIAGNOdent Pen is conditioned by the temperature and the need for calibration; this being especially important in long-term studies [3]. What is more, the apparatus is very sensitive to the contamination of dental tissues, such as dental deposits, discoloration of not carious origin, as well as polishing paste residues. In such cases, it may indicate false-positive results

DIAGNOcam (KaVo, Germany) is the newest device useful in the diagnosis of proximal caries, especially of the molars and premolars in the case of hidden caries. It is a kind of intra-oral video camera with black-and-white imaging in the form of shades of gray. Building on the achievements of digital fiber-optic transillumination in applying visible cold light, the DIAGNOcam device uses invisible light in the near infrared (NIR) to illuminate dental tissues. The device's flexible fiber optic tips (the arms of the DIAGNOcam device in the shape of pliers) emit light through the gingiva and alveolar bone through to the root of the tooth, and from there, to the crown. While the image is taken, the arms cover the tooth from the side of the proper and vestibular oral cavity. However, to obtain a clear picture, one should be aware of prior drying the surface of the tooth and switching off the flashlight of the unit, as well as setting the camera sensor parallel to the occlusal plane $[19,26]$.

So far, clinical studies show the usefulness of the DIAGNOcam device for dental practice in the evaluation of proximal caries. A comparison of the method of tissue testing using the near infra-red light with the method of bitewing projection, has demonstrated a compatibility of the diagnosis in $95.3 \%$ of cases of caries in the dentin [26]. Based on extensive investigations of molars and premolars in patients, and an evaluation of the images obtained by the DIAGNOcam device, adequate therapeutic treatment has been proposed according to the extent of caries. The recommendations are based upon the clinical experience of the authors of the scale, the results of which are assigned to the appropriate situation, and have been confirmed by visualization, using the DIAGNOcam laser video camera, thus, a classification of one to five has evolved. The scale range of the seriousness of the caries facilitates the interpretation of indications for the dentist when using DIAGNOcam.

The subsequent treatment can be preventive and minimally invasive as a medical procedure, but can also be invasive, depending on the severity of the found carious lesions. Preventive measures include the application of fluoride preparations in the dental office, recommendations for proper nutrition and diet with limited cariogenic products and instruction on proper oral hygiene. Additionally, in some situations, tooth sealing and infiltration are recommended. It is also important that the carious process be monitored. However, as with each device, DIAGNOcam has some limitations. It does not allow for the assessment of the periodontal tissues, and it is difficult to diagnose the development of caries under fillings, especially amalgam fillings. However, this is an innovative method for the imaging of proximal caries of the posterior teeth, and allows for the opportunity to archive images that are taken in a few seconds. Thus the benefits of employing the device has already found recognition among both physicians and patients [19].

\section{SUMMARY}

Carious lesions that initiate on the smooth proximal surfaces of the enamel between the point of contact and the gingival papilla, are characteristic, evidencing a broad surface of the lesion onset and a cone-shaped progression in the direction of the dentin-enamel junction (DEJ). After crossing the DEJ, the carious process expands sideways. This specificity of changes and space makes none of the standard diagnostic methods exclude the possibility of misdiagnosis of proximal caries. However, with the progress of the carious process, the effectiveness of these methods increases $[8,11,12,17]$. Therefore, during the diagnosing of doubtful cases, it is advisable to use several methods of testing, along with the simultaneous individual assessment of caries risk factors, such as oral hygiene, frequency of eating sweets or the number of active caries foci. The therapeutic decision regarding the proximal surfaces may also be influenced by the increase of the value GI (Gingival Index) [23].

\section{REFERENCES}

1. Anusavice K.J.: Present and future approaches for the control of caries. J. Dent. Educ., 69, 538, 2005.

2. Boguszewska-Gutenbaum H. et al.: Rozmieszczenie ubytków próchnicowych na poszczególnych powierzchniach w zębach mlecznych u dzieci do 36 miesiąca życia. Czas. Stomat., 50, 795, 1997.

3. Brown A., Krause F., Jepsen S.: The influence of the calibration mode of a laser fluorescence device on caries detection. Caries Res., 39, 144, 2005.

4. Chłapowska J., Żmijewska C.: Diagnostyka próchnicy powierzchni stycznych w badaniu klinicznym, transiluminacyjnym i radiologicznym. Stom. Współcz., 6, 32, 1999.

5. Forgie A.H., Pine C.M., Pitts N.B.: The assessment of an intra-oral video camera as an aid to occlusal caries detection. Int. Dent. J., 53, 3, 2003.

6. Haak R., Wicht M.J., Noack M.J.: Conventional, digital and contrastenhanced bitewing radiographs in the decision to restore approximal carious lesions. Caries Res., 35, 193, 2001.

7. Hintze H: Screening with conventional and digital bite-wing radiography, compared to clinical examination alone for caries detection in low-risk children. Caries Res., 27, 499, 1993.

8. Hintze H., Wenzel A.: Diagnostic outcome of methods frequently used for caries validation. A comparison of clinical examination, radiography and histology following hemi-sectioning and serial tooth sectioning. Caries Res., 37, 115, 2003.

9. Hintze H., Wenzel A., Danielsen B.: Behaviour of approximal carious lesions assessed by clinical examination after tooth separation and radiography: a 2.5- year longitudinal study in young adults. Caries Res., 33, 415, 1999.

10. Huysman M.C, Longbottom C.: The challenges of validating diagnostic methods and selecting appropriate gold standards. J. Dent. Res., 83, C48, 2004. 
11. Jędrychowska P., Zarzecka J.: Wybrane, współczesne metody diagnozowania początkowych zmian próchnicowych. Por. Stomat. 6, 22, 2006.

12. Kulczyk T.: Wykrywanie ognisk próchnicy za pomocą zdjęć skrzydłowo-zgryzowych. Mag. Stomat., 14, 31, 2004.

13. Kühnisch J., Bucher K., Hickel R.: The intra/inter-examiner reproducibility of the new DIAGNOdent Pen on occlusal sites. J. Dent., 35, 509, 2007.

14. Lussi A. et al.: Detection of approximal caries with a new laser fluorescence device. Caries Res., 40, 97, 2006.

15. Marsh P., Martin M.: Mikrobiologia jamy ustnej. PWN Warszawa 1994.

16. Maupomé G., Sheiham A.: Decisions on diagnosis and management of approximal caries by final-year dental students. Dentomaxillofac. Radiol., 26, 107, 1997.

17. Mirska-Miętek M.: Diagnozowanie zmian próchnicowych na powierzchniach stycznych zębów stałych. Ann. Acad. Med. Stetin., $56,70,2010$.

18. Nyvad B.: Diagnosis versus detection of caries. Caries Res., 38, 192, 2004.

19. Paruzel-Pliskowska A. et al.: Wykrywanie próchnicy pierwotnej za pomocą zdjęć ortopantomograficznych oraz aparatu DIAGNOcam (KaVo) - doniesienie wstępne. Stom. Wspótcz., 21, 18, 2014.

20. Pitts N.B.: Clinical diagnosis of dental caries. A European perspective. J. Dent. Educ., 65, 973, 2001.

21. Pitts N.B.: Modern concepts of caries measurement. J. Dent. Res., 83, C43, 2004.
22. Popoola B.O. et al.: A comparison of clinical and radiographic caries diagnosis on posterior teeth of children seen at a Nigerian teaching hospital. Afr. J. Med. Med. Sci., 39, 41, 2010.

23. Ratledge D.K., Kidd E.A.M., Beighton D.: A clinical and microbiological study of approximal carious lesions. Part 1: the relationship between cavitation, radiographic lesion depth, the site-specific gingival index and the level of infection of the dentine. Caries Res., 35, 3, 2001.

24. Różyło-Kalinowska I., Różyło T.K.: Zdjęcia rentgenowskie w stomatologii a narażenie na promieniowanie jonizujące. Mag. Stomat., 12, 40, 2002.

25. Schmid R. et al.: Amine fluoride and monofluorophosphate: I. Historical review of fluoride dentifrices. ASDC J. Dent. Child., 51, 99, 1984.

26. Söchtig F., Hickel R, Kühnisch J.: Caries detection and diagnosis with near-infrared light transillumination: clinical experiences. Quintessence Int.,45, 531, 2014.

27. Szafrańska B, Waszkiel D.: Rozmieszczenie ubytków próchnicowych na poszczególnych powierzchniach zębów mlecznych u dzieci białostockich. Nowa Stom., 14, 68, 2009.

28. Wenzel A., Hintze H.: The choice of gold standard for evaluating tests for caries diagnosis. Dentomaxillofac. Radiol., 28, 132, 1999.

29. Wenzel A, Fejerskov O: Validity of diagnosis of questionable caries lesions in occlusal surfaces of extracted third molars. Caries Res., 26, 188, 1992.

30. Woźniak J. et al.: Powtarzalność pomiarów fluorescencji za pomocą aparatu Diagnodent ${ }^{\oplus}$ na powierzchniach żujących zębów trzonowych w warunkach in vitro. Dent. Med. Probl., 45, 255, 2008. 